\title{
The Comparative Experimental Study of the Teaching Effect between Jigsaw Teaching Method and Traditional Teaching One in Medical Literature Retrieval Course
}

\author{
Wei Wang* \\ Xi'an Medical University \\ Xi'an Shaanxi
}

\begin{abstract}
To find a more appropriate teaching method for medical literature retrieval, two teaching methods were used and implementation effects were compared in the actual teaching process. 113 college undergraduates (selected at random cluster) were divided into Jigsaw teaching group and traditional teaching group to do the experiment research and SPSS22.0 was used for statistical analysis. And questionnaires were also used to gather the students' feedback information on the two teaching methods in the aspects of learning ability, learning effects, power of expression and so on. It showed that jigsaw teaching method was superior to traditional one in the aspects of curriculum preparation, content mastery and final test. It was a more suitable teaching method for medical literature retrieval course, and it was worth popularizing.
\end{abstract}

Keywords-Jigsaw teaching method, traditional teaching method, medical literature retrieval course, teaching effect, comparative experimental study

\section{INTRODUCTION}

Jigsaw teaching method is a cooperative learning method proposed by Elliot Aronson, a famous American educator and sociologist in the 1970s. Every classroom teaching (about 2 class hours) is regarded as complete and independent teaching content. When the teacher carries out teaching activities, the teaching content is divided into several parts and then is reassembled into a whole. The Jigsaw Classroom is a cooperative learning technique that promotes better learning, improves student motivation, and increases the enjoyment of the learning experience[1].

Basic requirements for the Jigsaw teaching activities: (1) teachers should be familiar with the resources related to the course (namely paper resources and electronic resources), can screen valuable reference books and provide required and selected reading lists for students, especially the excellent electronic resources; (2) teachers should grasp the teaching content macroscopically and allocate the teaching time reasonably; (3) every single content is presented as a topic and can be divided clearly and explicitly into several subtasks; (4) students are divided into several Jigsaw groups. The number of team members and task segmentation is required to be consistent; (5) the "expert group" is composed of students who are responsible for the same subtask from different Jigsaw groups.

The basic steps of Jigsaw teaching include: (1) subtasks are assigned for the Jigsaw group members and pre-class preparation jobs should be done ahead of class. The reference lists and resource acquisition paths are provided for them in advance and preparation should be serious and thorough. (2) on the class, the "expert group" members shall interact and discuss with each other, and each sub-task shall form a unified "expert opinion". If there is a difference in opinion, the teacher shall give guidance; (3) the members of the "expert group" return to the Jigsaw group and share the "expert opinions" with other members; (4) Jigsaw groups do the summary and give a mastery report for all the students; (5) teachers summarize or supplement the Jigsaw report and evaluate students' performance.

Jigsaw teaching method has been proved to be an effective method that can significantly improve students' participation and learning enthusiasm [2], which is particularly suitable for teaching activities that focus on practical, deep and persistent learning [3].

Medical literature retrieval was set up in China in the 1980s, and it has been developed for almost forty years. It is a kind of course that emphasizes more on practical teaching and learning. It focuses on training medical students on how to collect and process medical information, and how to analyze and solve problems. The aim of the course is to stimulate medical students' independent thinking and innovation consciousness and to improve their information consciousness and information quality. During these years, the main teaching method is still the traditional one while it has certain disadvantages in the mastery of retrieval methods and the cultivation of retrieval ability. It is necessary to find a more suitable teaching method for this course. So the Jigsaw teaching method is introduced and a contrast experiment has been implemented between these two different teaching methods. The aim is to collect some original feedback data to accumulate some experiences for the innovation of teaching mode. 


\section{ReseARCh OBJeCt AND Method}

\section{A. Research object}

The experimental subject is 113 undergraduate students from the pharmaceutical department of grade 2015, including 57 students from pharmaceutical major and 56 students from traditional Chinese medicine major. The textbook is medical literature retrieval and thesis writing (4ed) (Guo Jijun, People's health publishing press, 2013).

\section{B. Research methods}

1) Methods: questionnaires, tests and randomized controlled trials

Questionnaires: Based on Marsh Student Evaluation of Educational Quality (SEEQ)[4][5] and Mahfooz Ansari and Mustafa Achoui Ansari Teaching Feedback Survey[6], Questionnaire on the implementation effect of teaching mode based on Jigsaw teaching method/traditional teaching method was compiled to compare the differences in learning ability, learning effect and expression ability between the two teaching methods. The answer options of the questionnaire were all set quantitatively according to the 5-level equidistant grading standard in Likert scale.

Tests: with the implementation of the two teaching methods, the mastery of learning content was tracked actively and the pre-learning test and post-learing test were conducted respectively to evaluate the teaching effects. Pre-learning evaluation meant that students were tested and the results were counted before the class, Post- learning evaluation meant that students were tested again and the results were counted after the class. Two results were compared randomly to evaluate the teaching effect in students' mastery of in-class course contents. In the end, students were tested by the final test to compare the whole teaching effect.

Randomized controlled trial: Pharmacy Class with 57 students was the experimental class adopted by the Jigsaw teaching method, while Traditional Chinese Medicine Class with 56 students was the control class adopted by the traditional teaching method. After a whole round of teaching activities, the teaching effect was compared.

\section{2) Evaluation methodology}

SPSS22.0 was used to do the data statistics, such as independent sample $t$ test, paired sample $t$ test and so on.

\section{RESEARCH RESULTS}

\section{A. Comparison of pre-class test and after-class test in} medical literature retrieval under the two teaching modes

Pre-class and after-class tests were randomly selected for three times in the experimental class and the control class, and the test results were matched with the paired samples $t$ test. The results were shown in TABLE I:

TABLE I. PAIRED SAMPLES TEST

\begin{tabular}{|c|c|c|c|c|c|c|c|c|c|}
\hline & \multicolumn{5}{|c|}{ Paired Differences } & \multirow{3}{*}{$\mathrm{t}$} & \multirow{3}{*}{ df } & \multirow{3}{*}{$\begin{array}{c}\text { Sig. } \\
\text { (2-tailed) }\end{array}$} \\
\hline & & \multirow{2}{*}{ Mean } & \multirow{2}{*}{$\begin{array}{c}\text { Std. } \\
\text { Deviation }\end{array}$} & \multirow{2}{*}{$\begin{array}{c}\text { Std. Error } \\
\text { Mean }\end{array}$} & \multicolumn{2}{|c|}{ 95\% Confidence Interval of the Difference } & & & \\
\hline & & & & & Lower & Upper & & & \\
\hline \multirow{3}{*}{$\begin{array}{l}\text { Traditional } \\
\text { teaching } \\
\text { method }\end{array}$} & After class test I- pre-class test I & 41.054 & 9.834 & 1.314 & 38.420 & 43.687 & 31.240 & 55 & .000 \\
\hline & After class test II - pre-class test II & 40.196 & 8.094 & 1.082 & 38.029 & 42.364 & 37.166 & 55 & .000 \\
\hline & $\begin{array}{l}\text { After class test III - pre-class test } \\
\text { III }\end{array}$ & 40.536 & 8.568 & 1.145 & 38.241 & 42.830 & 35.402 & 55 & .000 \\
\hline \multirow{3}{*}{$\begin{array}{l}\text { Jigsaw } \\
\text { teaching } \\
\text { method }\end{array}$} & After class test I- pre-class test I & 66.053 & 5.881 & .779 & 64.492 & 67.613 & 84.796 & 56 & .000 \\
\hline & After class test II - pre-class test II & 62.930 & 6.135 & .813 & 61.302 & 64.558 & 77.443 & 56 & .000 \\
\hline & After class test III -pre-class test III & 65.018 & 6.186 & .819 & 63.376 & 66.659 & 79.351 & 56 & .000 \\
\hline
\end{tabular}

It can be seen from TABLE I that the t-test Sig values of the three paired samples were all $0.000, \mathrm{p}<0.001$, which meant that both teaching methods had certain improvements in students' mastery of learning content.

However, the number of Mean was increased by 41.054 , 40.196 and 40.536 respectively through the traditional teaching method while increased by 66.053, 62.930 and 65.018 respectively through Jigsaw teaching method. The former average score was increased by 40 scores while the latter was increased by 65 scores. So, Jigsaw teaching method was superior to the traditional teaching method in terms of the mastery of single learning content.

\section{B. Comparison of the final test of medical literature retrieval} course under the two teaching modes

After completing the teaching and learning of the whole semester, the final test was conducted on the experimental class and the control one. The students of the experimental class were required to do the closed-book exam, while the control class had no special requirements (open or closed was
OK). The test results were tested by independent sample $t$ test, and the results were shown in TABLE I and TABLE II:

TABLE II. GROUP STATISTICS

\begin{tabular}{|c|c|c|c|c|}
\hline Teaching Method & $\mathrm{N}$ & Mean & Std. Deviation & $\begin{array}{c}\text { Std. Error } \\
\text { Mean }\end{array}$ \\
\hline $\begin{array}{c}\text { Traditional teaching } \\
\text { method }\end{array}$ & 56 & 75.750 & 4.0283 & .5383 \\
\cline { 3 - 5 } & 57 & 84.702 & 2.7514 & .3644 \\
\hline
\end{tabular}

As can be seen from TABLE II, the mean, the standard deviation and the standard error mean of the sample were $75.750,4.0283$ and 0.5383 in the control class, while those were 84.702, 2.7514, 0.3644 in the experimental class. From the average scores of the final test, Jigsaw teaching method group was higher than the traditional one. 
TABLE III. INDEPENDENT-SAMPLES T TEST

\begin{tabular}{|c|c|c|c|c|c|c|c|c|c|c|}
\hline & \multicolumn{2}{|c|}{$\begin{array}{r}\text { Levene's Test for } \\
\text { Equality of Variances }\end{array}$} & \multicolumn{7}{|c|}{ t-test for Equality of Means } \\
\hline & & \multirow[t]{2}{*}{$\mathrm{F}$} & \multirow{2}{*}{ Sig. } & \multirow{2}{*}{$\mathrm{t}$} & \multirow{2}{*}{$\mathrm{df}$} & \multirow{2}{*}{$\begin{array}{c}\text { Sig. } \\
\text { (2-tailed) }\end{array}$} & \multirow{2}{*}{$\begin{array}{c}\text { Mean } \\
\text { Difference }\end{array}$} & \multirow{2}{*}{$\begin{array}{l}\text { Std. Error } \\
\text { Difference }\end{array}$} & \multicolumn{2}{|c|}{$\begin{array}{c}\text { 95\% Confidence Interval of the } \\
\text { Difference }\end{array}$} \\
\hline & & & & & & & & & Lower & Upper \\
\hline \multirow{2}{*}{$\begin{array}{c}\text { Test } \\
\text { scores }\end{array}$} & $\begin{array}{c}\text { Equal variances } \\
\text { assumed }\end{array}$ & 6.122 & .015 & -13.815 & 111 & .000 & -8.9518 & .6480 & -10.2357 & -7.6678 \\
\hline & $\begin{array}{c}\text { Equal variances not } \\
\text { assumed }\end{array}$ & & & -13.771 & 96.964 & .000 & -8.9518 & .6501 & -10.2420 & -7.6616 \\
\hline
\end{tabular}

The comparison of teaching effect could be seen clearly from the TABLE III. The independent sample $t$ test results were less than 0.05, which meant there were significant differences between the two teaching methods and the teaching effect of Jigsaw teaching method was obviously better than that of a traditional one.

\section{The reliability and validity test results of the questionnaire}

In order to consider the quality and efficiency of the questionnaire, two round tests were conducted to evaluate its reliability and validity. SPSS22.0 analysis software was used for item analysis, reliability analysis (i.e. internal consistency analysis) of the initial questionnaire and exploratory factor analysis invalidity test. Some poor items were deleted according to the results of the analysis tests. After revision, the Cronhach's alpha coefficient of the final questionnaire was greater than 0.7 , project analysis was less than 0.05 , the confirmatory factor analysis (CFA) and the combination of questionnaire dimension reliability were all above 0.6 , the average variance extracted (AVE) was greater than or equal to the international general standard 0.5. It showed that the questionnaire had good internal consistency, each item was good distinction between sex and reliability, and it was a valid questionnaire.

\section{The results of the questionnaire survey}

A total of 57 questionnaires were distributed in the experimental class and 49 questionnaires were recovered, the recovery rate was $85.9 \%$. A total of 56 questionnaires were distributed in the control class, and 45 questionnaires were recovered, the effective recovery rate was $80.3 \%$. Both were within effective recovery rate. The survey results were as followings:

$69.39 \%$ of the experimental class considered that Jigsaw teaching method was very attractive to them, while $64.44 \%$ of the control class said that they were not interested in the traditional teaching method; $77.55 \%$ of experimental class students deemed that Jigsaw teaching method could stimulate their interests in learning, while only $4.44 \%$ of control class students supported the traditional one; $71.43 \%$ of experimental class students said that most contents taught on the class could be mastered through Jigsaw teaching method, and $6.12 \%$ of them could master the whole. However, 35.56\% of control class students said that most contents could be mastered by the traditional teaching method; Through the study of literature retrieval course, $69.39 \%$ of the experimental class said that they were very familiar with the applicable scope of various electronic databases in the library. In the further study, they had the ability to find appropriate databases according to their learning needs, $40 \%$ of the control class said that they could, and $2.22 \%$ of the students were still unfamiliar with the databases after the teacher's explanation. $79.59 \%$ of the students approved the Jigsaw teaching method and 20.41\% approved it very much. $68.89 \%$ of the students using traditional teaching method were willing to try new teaching mode and $26.67 \%$ of them had a strong will for it.

\section{CONCLUSION}

(1) Every student's preparation job is emphasized in Jigsaw method. Students are encouraged to dig deep into a task and the Jigsaw method has been proved its effectiveness in reducing students' blindness in the preparatory stage. When facing problems, students can turn to paper or the Internet or both. Medical literature retrieval course needs to teach students the ability of searching, screening and extracting information, which has been gradually mastered by students in the process of problem solving.

(2) Students are valued as part of the 'expert group' discussion and feedback process. It greatly solves the problem that some students do not effectively participate in the course learning. Discussion is helpful for students to draw nutrients from peers and learn from each other. The highly interactive network interaction enables students to exercise their expression, communication, understanding and summarizing abilities and various learning methods can enrich students' ideas.

(3) students are put actually in the main body of learning in the Jigsaw class, and each group member is unique and irreplaceable. One time of absence from class will not guarantee the integrity of the whole group's learning task. The teacher does not need to call the roll, and the attendance rate of students is very high.

(4) Teachers truly walk from the platform to students in the Jigsaw class, participate in the discussion of students, and solve students' questions. Students' understanding of the same problem from different perspectives can also broaden teachers' thinking, so as to achieve true teaching and learning. It does not liberate teachers from teaching, but has higher professional requirements for teachers. Teachers need to know various resources in relation to the course, and extract high-quality resources for students to recommend. Facing a new course, students' role of "experts" depends to some extent on the quality of the teacher's recommendation materials

In a word, a proper teaching method is a better teaching method, and a good teaching method teaches students not only the course content, but also the cultivation of students' ability 
to think, solve and communicate. Through the comparative teaching practice, Jigsaw teaching method is better than the traditional teaching method in terms of various teaching indicators, which is suitable for the teaching of medical literature retrieval course and worthy of promotion.

\section{REFERENCES}

[1] Yoshida, M. Communication Jigsaw: A teaching method that promotes scholarly communication[J]. International Journal of Emerging Technologies in Learning, 2018, 13(10), 208-224

[2] Wan Jian, Zheng Jinhao, Lin Zhaofeng, Li Wenfang, Shan Yi. Jigsaw, The Teaching Effect Comparison between Jigsaw Teaching Method and
PBL Teaching Method in Clinical Practice [J]. Health vocational education, 2016, 34(24):145-147.

[3] Phillips J, Fusco J. Using the Jigsaw Technique to Teach Clinical Controversy in a Clinical Skills Course[J]. Am J Pharm Educ, 2015, 79(6): 90.

[4] Marsh H W. SEEQ: A reliable, valid, and useful instrument for collecting students' evaluations of university teaching[J]. British Journal of Educational Psychology, 2011, 52(1):77-95.

[5] Alexandre J. S. Morin; Herbert W. Marsh. Disentangling Shape from Level Effects in Person-Centered Analyses: An Illustration Based on University Teachers' Multidimensional Profiles of Effectiveness[J]. Structural Equation Modeling.2015, Vol.22 (No.1): 39-59.

[6] Mikail Ibrahim.A Psychometric Evaluation of Two Teaching Effectiveness Scales[J].Journal of Sustainable Development.2012, Vol.5 (No.7) 